\title{
Culture-independent quantification of Salmonellae in food by molecular beacon based real-time PCR
}

\author{
Rajesh Singh Tomar, Anurag Jyoti* \\ Amity Institute of Biotechnology, Amity University Madhya Pradesh, Gwalior, India.
}

\begin{tabular}{|c|c|}
\hline ARTICLE INFO & ABSTRACT \\
\hline Article history: & \multirow{9}{*}{$\begin{array}{l}\text { The present study has explored the culture-independent quantification of Salmonellae in selected food items by } \\
\text { targeting invA gene using molecular beacon (MB) based real-time PCR assay. The assay could detect ten } \\
\text { Genome Equivalents/PCR (GE/PCR) of reference strain S. typhimurium MTCC } 98 \text {. The assay could detect } \\
\text { Salmonellae in selected food samples (vegetables, street foods, fruit juices) collected from Gwalior city. } \\
\text { Coriander poses the highest concentration of Salmonellae }\left(1.058 \times 10^{7} \pm 211734 \mathrm{CFU} / 25 \mathrm{~g} \text { ) in vegetables followed }\right. \\
\text { by panipuri }\left(6.73 \times 10^{6} \pm 309502 \mathrm{CFU} / 100 \mathrm{ml} \text { ) in street food samples and Pineapple juice }\left(8.15 \times 10^{3} \pm 293 \mathrm{CFU} / 100\right.\right. \\
\text { ml). Egg being the potential reservoir of Salmonellae was also contaminated }\left(5.2 \times 10^{3} \pm 136 \mathrm{CFU} / 25 \mathrm{~g}\right) \text {. The } \\
\text { present assay is culture independent without pre-enrichment of samples. The quantification of Salmonella spp. } \\
\text { in food samples can be completed in } 4-6 \mathrm{~h} \text { by the assay developed in the present study, in comparison to culture } \\
\text { based method which requires } 2 \text { to } 3 \text { days. }\end{array}$} \\
\hline Received on: 17/08/2016 & \\
\hline Revised on: $08 / 09 / 2016$ & \\
\hline Accepted on: 07/10/2016 & \\
\hline Available online: $29 / 11 / 2016$ & \\
\hline Key words: & \\
\hline Salmonellae, PCR & \\
\hline (Polymerase Chain & \\
\hline Reaction), Molecular beacon, & \\
\hline
\end{tabular}

\section{INTRODUCTION}

Salmonella, prevalent in food is one of the deadliest pathogens, causes major health and economic losses worldwide (Agarwal et al., 2015; de Jong et al., 2006; Voetsch, et al., 2004). Eggs, poultry meat, fruits and vegetables are the important sources of human salmonellosis (Hald et al., 2004). In a developing country like India, infections due to contaminated food are oftenly reported. India has been categorized under the high risk zone of typhoid caused by Salmonella serovars. Most of the disease incidences occur due to the improper management and lack of quantitative data. Identification of potentially pathogenic Salmonella serovars is currently a labor intensive process. The initial isolation of this microbe from food samples is difficult as the small numbers of bacteria can be present in the sample (Baylis et al., 2000). This requires the preenrichment step

* Corresponding Author

Dr. Anurag Jyoti, Amity Institute of Biotechnology,

Amity University Madhya Pradesh, Gwalior, India.

Email ID: ajyoti @ gwa.amity.edu,Phone: +91-7898805402 prior the quantification. The current established method for isolation of Salmonella from food matrices is a well established procedure-ISO 6579, which is laborious and time-consuming and takes almost 5 days to complete (Tomar et al., 2015; Agarwal et al., 2014; Uyttendaele et al., 2003). Kauff-man-White serotyping system is used to characterize Salmonella into its subspecies, based on the variability of the $\mathrm{O}, \mathrm{H}$ and $\mathrm{Vi}$ antigens (Yoshida et al., 2007). The serotyping method is unable to identify $S$. enterica which lack either the $\mathrm{O}$ antigen alone or both the $\mathrm{O}$ and the $\mathrm{H}$ antigens (Hoorfar et al., 2000). Polymerase Chain Reaction (PCR) is the modern nucleic acid based diagnostic method has been explored for the detection of Salmonella serovars in food samples (Malkawi et al., 2003).

Though the PCR is specific technique, it still lacks the sensitivity and a post PCR processing is required, which limit its establishment for diagnosis of Salmonella. The invA gene encodes invasion associated protein is present in Salmonella serotypes including all subspecies (Galan et al., 1996; Malorny et al., 2003; Hadjinicolaou et al., 2009). The invA, being the signature gene is used for quantification of Salmonella spp. in food samples. 
Therefore, there is an urgent need for the development of assay for the specific and sensitive detection of Salmonella in food samples. Quantitative PCR, oftenly called as real-time PCR is a major revolution in molecular diagnostic methodologies. Realtime PCR is highly sensitive, specific and allows accurate quantification of the target DNA. Real-time PCR through use of fluorescence detection strategies allows the quantification of nucleic acid in a reaction without post-PCR processing. Real-time PCR based methods with advantages of quantification, sensitivity, and rapidity, have been reported to detect Salmonella in various food items (Liming et al., 2004; Bhagwat, 2004; Park et al., 2008; Singh et al., 2011). Furthermore, a number of commercial realtime PCR systems have been used for detection of Salmonella in meat samples (Perelle et al., 2004; Cheung et al., 2004; Patel et al., 2006). However, majority of these assays need pre-enrichment of the samples and often require 17-20 $\mathrm{h}$ for quantitative enumeration of pathogen.

The present study aims to evaluate the culture-free highly sensitive quantitative PCR assay using MB probe for quantification of Salmonellae in various food matrices collected from local market in Gwalior city.

\section{MATERIALS AND METHODS}

\section{Primers and probe}

In the present study, the invA primer set $\left(5^{\prime}\right.$ GTGAAATTATCGCCACGTTCGGGCAA-3' and 5'TCATCGCACCGTCAAAGGAACC-3'), was adopted (Rahn et al., 1992). The primer set, producing 284 bp shows high specificity for all subspecies of Salmonella serotypes (Malorny et al., 2003). To ascertain the in-silico specificity, the primers wereanalysed by nucleotide BLAST programme.

The molecular beacon for specific detection of Salmonella spp. harboring invA gene was adopted from Jyoti et al. (2010). The molecular beacon (5'CCAGGCTTCCAGTACGCTTCGCCGTTCGCCTGG-3') was analysed for correct stem loop configuration secondary structure formation in mFold server (http://mfold.rna.albany.edu/?q=mfold/DNA-Folding-Form) to ensure correct folding of the probe. The MB was modified at 5' end with fluorophore (FAM: 6- carboxy-fluorescein) and at 3' end with quencher DABCYL.

\section{Bacterial strains and specificity of the assay}

Bacterial strains used to determine the specificity of PCR primers are listed in table 1. The reference strains (S. typhimurium MTCC 98, S. typhi MTCC 735) were procured from Microbial Type Culture Collection (MTCC) at Institute of Microbial Technology (IMTECH), Chandigarh, India.

S. typhimurium MTCC98 was used for generation of standard curve for the real-time PCR. The inclusivity and exclusivity of the computed MB probe was checked using reference strains of Salmonella and other genera.

\section{Food samples}

Street food items included Panipuri (water), Egg, Noodles and fruit juices like Citrus (Citrus limetta), Pineapple (Ananas comosus), Sugarcane (Saccharum spp.) and Watermelon (Citrullus lanatus) were procured from local markets in Gwalior city. Apart from these vegetables used for garnishing the dishes such as fenugreek (Trigonella foenum-graecum), mint (Mentha spp.) and coriander (Coriandrum sativum) leaves were purchased from local markets. Fruit juices and water of panipuri (2 litres each) were filtered through sterilized muslin clothes to remove the coarse fibres. The leafy vegetables, $50 \mathrm{~g}$ each) were properly rinsed in $200 \mathrm{ml}$ saline with gentle shaking followed by sonication (cycle 0.5 for $20 \mathrm{~s}$ ) with output power of $200 \mathrm{~W}$ to transfer the microflora in saline. The sample volume was then reduced to 500 $\mu \mathrm{l}$ by centrifugation at $14000 \mathrm{x}$ g.

\section{Isolation of multigenomic DNA}

Multigenomic DNA was prepared using boiling prep method (Jyoti et al., 2010). Briefly, the concentrated sample was heated to boiling temperature for 30 minutes to ensure killing of all microflora followed by the release of their nucleic acids. The DNA was removed by centrifuging the debris at $8,000 \mathrm{x} g$ for 5 min. Further, the DNA in supernatant was precipitated using sodium acetate (0.3 M, pH 5.2) and ice cold ethanol. The precipitated DNA was pelleted by centrifugation at $12000 \mathrm{x}$ g for 5 min. DNA pellet was resuspended in $100 \mu \mathrm{TE}, \mathrm{pH} 8$ after washing thrice with $70 \%$ ethanol. The purity and yield of isolated DNA was determined using Spectrophotometer.

\section{Quantitative enumeration of Salmonellae using real-time PCR}

The virulent invA gene of Salmonella was targeted to quantify the Salmonellae in real life samples by real-time PCR. To determine the limit of detection of molecular beacon based quantitative PCR assay, a series of 10-fold serially diluted Salmonella typhimurium MTCC 98 pure culture genomic DNA $\left(10^{7}-1\right.$ GE/PCR) was analysed for real-time PCR amplification. Template DNA, primers and probe were added to PCR master mix. The final concentration of MB probe and primers were 200 $\mathrm{nM}$ and $400 \mathrm{nM}$ respectively. The temperature conditions were set as follows: initial denaturation of $95^{\circ} \mathrm{C}$ for $12 \mathrm{~min}$, followed by 48 cycles at $94{ }^{\circ} \mathrm{C}$ for $30 \mathrm{~s}, 54{ }^{\circ} \mathrm{C}$ for $30 \mathrm{~s}$ and $72{ }^{\circ} \mathrm{C}$ for $30 \mathrm{~s}$. Similar assay was performed with the Salmonella typhi MTCC 733, another strain of Salmonella. Purified multigenomic DNA $(5 \mu \mathrm{l})$ from environmental samples were diagnosed for under identical PCR conditions. This resulted in generation of a standard curve to quantify the load of Salmonellae in different food samples.

\section{RESULTS AND DISCUSSION}

\section{Generation of standard curve}

The present molecular beacon based assay detected 10 or more genomic equivalent (GE) of the reference strain per PCR per PCR of S. typhimurium MTCC 98 (Fig. 1). 

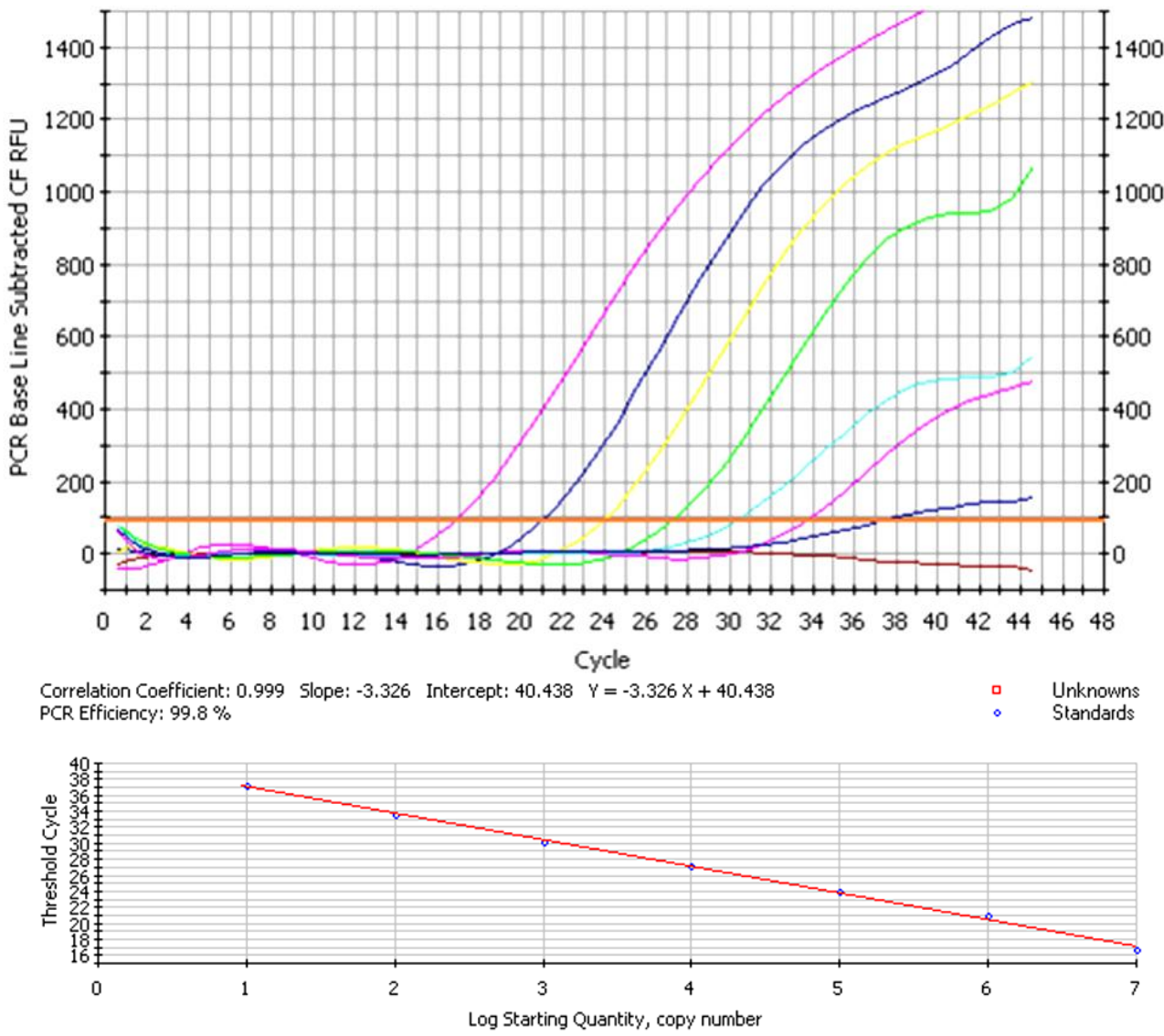

Fig. 1: Real-time PCR spectra (A) and Standard curve (B) obtained from $10^{7}$ down to 10 GE/PCR genomic DNA of S. typhimurium MTCC 98.

\section{Specificity of the test}

The developed real-time PCR assay is highly sensitive and specific to the Salmonella spp. The reference strains of Salmonella were positive for the invA gene. There was no amplification observed in E. coli reference strains. Recovery of the target organism or its nucleic acids from sample matrix is important for its detection. Reference strains of Salmonella were detected by the assay, whereas other genera were found negative. The assay developed based on invA gene is highly specific and sensitive for detection of Salmonella even in street food samples.

Table 1: Specificity of the molecular beacon targeting invA gene for detection of Salmonella spp

\begin{tabular}{lc}
\hline Reference Strains & invA gene \\
\hline Salmonella typhimurium MTCC 98 & + \\
Salmonella typhi MTCC 733 & + \\
E. coli MTCC723 (MTCC, Chandigarh) & - \\
\hline
\end{tabular}

\section{Detection of Salmonellae in food samples}

Food samples collected from Gwalior city were analysed for the presence of Salmonella spp. Panipuri (water), Egg, Noodles and fruit juices like Citrus, Pineapple were significantly contaminated with Salmonellae. Sugarcane and Watermelon juices were negative for the presence of Salmonellae. Leafy vegetables were contaminated with Salmonellae which on consumption may pose health risk to consumers. The contamination levels of
Salmonellae were varied significantly. Coriander poses the highest concentration of Salmonellae $\left(1.058 \times 10^{7} \pm 211734 \mathrm{CFU} / 25 \mathrm{~g}\right)$ in vegetables followed by panipuri $\left(6.73 \times 10^{6} \pm 309502 \mathrm{CFU} / 100 \mathrm{ml}\right)$ (Table 2) in street food samples and Pineapple juice $\left(8.15 \times 10^{3} \pm 293 \mathrm{CFU} / 100 \mathrm{ml}\right)$ (Table 3). Salmonellae are the leading food borne pathogens and can enter the food chain at any level (Malorny et al., 2008). A variety of food matrices are the potential reservoirs of Salmonella. Presence and long term persistence of Salmonella in surface waters is well documented (Moganedi et al., 2007; Jyoti et al., 2010). Leafy vegetables grown near the rural and urban interface of city are irrigated through the contaminated river/ pond water. Apart from these, the vegetables on the river bank are in constant exposure of this microbial flora. These contaminated vegetables are transported to the local markets and are improperly washed. In the present study, all the leafy vegetables which are used to garnish the dishes were found contaminated with Salmonellae.

Egg, being the potential reservoir of Salmonellae was also contaminated $\left(5.2 \times 10^{3} \pm 136 \mathrm{CFU} / 25 \mathrm{~g}\right)$. Poultry samples are the primary reservoirs of Salmonellae. Egg shells bearing fecal matter of chickens are contaminated with the Salmonella are stored at room temperature, which helps these organisms to multiply fast during transportation and handling (Jamshidi et al., 2010). Sugarcane and Watermelon were negative for the presence of Salmonellae (Table 3). 
Table 2: Contamination of vegetables used for garnishing the dishes and street food items by Salmonellae.

\begin{tabular}{|c|c|c|}
\hline S. No. & Food samples & Salmonellae (CFU/25 g produce) \\
\hline \multicolumn{3}{|c|}{ Vegetables used for garneshing the dishes } \\
\hline 1. & Fenugreek (Methi) & $1.57 \times 10^{6} \pm 72220$ \\
\hline 2. & Mint & $1.02 \times 10^{6} \pm 35700$ \\
\hline 3. & Coriander & $1.058 \times 10^{7} \pm 211734$ \\
\hline \multicolumn{3}{|c|}{ Street foods } \\
\hline 1. & Panipuri & $6.73 \times 10^{6} \pm 309502$ \\
\hline 2. & Egg & $5.2 \times 10^{3} \pm 136$ \\
\hline 3. & Noodles (Chowmin) & $9.1 \times 10^{2} \pm 22$ \\
\hline
\end{tabular}

Values are mean $(\mathrm{n}=5) \pm$ S.D.

Table 3: Contamination of street fruit juices by Salmonellae.

\begin{tabular}{lll}
\hline S. No. & \multicolumn{1}{c}{ Juices } & \multicolumn{1}{c}{ Salmonellae $(\mathbf{C F U} / \mathbf{m l})$} \\
\hline 1. & Citrus (Mausambi) & $3.4 \times 10^{3} \pm 79$ \\
2. & Pineapple & $8.15 \times 10^{3} \pm 293$ \\
3. & Sugarcane & N.D. \\
4. & Watermelon & N.D. \\
$*$ Values are & mean $(\mathrm{n}=5) \pm$ S.D. N.D. & Not detected.
\end{tabular}

The rapidity and sensitivity of detection technique plays an enormous impact on quantitative microbial risk assessment for generation of quantitative data on food samples. A number of techniques are available which rely on the enrichment of sample prior to PCR (Myint et al., 2006; Malorny et al., 2007). In a study, an $18 \mathrm{~h}$ of pre-enrichment was required for detection of all five chicken samples (Myint et al., 2006).

The present culture independent assay is more rapid than other previous reports (Singh et al., 2011; Hadjinicolaou et al., 2009; Malorny et al., 2007; Bohaychuk et al., 2007) which require at least 6, 8, 24 and $52 \mathrm{~h}$ for detection of Salmonella in food and other samples. The present assay is culture independent without pre-enrichment of samples. The quantification of Salmonella spp. in food samples can be completed in 4-6 $\mathrm{h}$ by the assay developed in the present study, in comparison to culture based method which requires 2 to 3 days. Therefore, the culture-independent real-time PCR assay developed in this study for quantitative enumeration of Salmonella spp. in food samples is rapid, accurate and sensitive.

\section{ACKNOWLEDGEMENT}

We wish to express our sincere acknowledgement to Dr. Ashok Kumar Chauhan, President, RBEF parent organization of Amity University Madhya Pradesh (AUMP), Dr. Aseem Chauhan, Additional President, RBEF and chairman of AUMP; Lt. Gen. V.K. Sharma, AVSM (Retd.), Vice Chancellor of AUMP Gwalior, for providing their valuable support, necessary facilities and encouragement throughout the work.

Financial support and sponsorship: This work was financially supported by Madhya Pradesh Council of Science and Technology (MPCST), Bhopal.

Conflict of Interests: There are no conflicts of interest.

\section{REFERENCES}

Agarwal M, Jyoti A, Tomar RS. Prevalence of antimicrobial resistance and virulence determinant of Salmonellae isolated from potable water. Int. Journ. Pharm. Bio Sci, 2015; 6: 997-1004.

Agarwal M, Tomar RS, Jyoti A. Detection of Water-borne Pathogenic Bacteria: Where Molecular Methods Rule. Intern Journ of Multidisc. Curr. Res, 2014; 2: 351- 358.

Baylis CL, MacPhee S, Betts RP. Comparison of methods for the recovery and detection of low levels of injured Salmonella in ice cream and milk powder. Lett. Appl. Microbiol, 2000; 30: 320-324.

de Jong B, Ekdahl K. The comparative burden of salmonellosis in the European Union member states, associated and candidate countries. BMC Pub, Heal, 2006; 6: 4.

Bhagwat AA. Rapid detection of Salmonella from vegetable rinse-water using real-time PCR. Food Microbiol, 2004; 21: 73-78.

Cheung PY, Chan CW, Wong W, Cheung TL, Kam KM. Evaluation of two real-time polymerase chain reaction pathogen detection kits for Salmonella spp. in food. Lett. Appl. Microbiol, 2004; 39: 509-515.

Galan JE. Molecular bases of Salmonella entry into host cells. Mol. Microbiol, 1996; 20: 263-271.

Hadjinicolaou AV, Demetriou VL, Emmanuel MA, Kakoyiannis CK, Kostrikis LG.Molecular beacon-based real-time PCR detection of primary isolates of Salmonella typhimurium and Salmonella Enteritidis in environmental and clinical samples. BMC Microbiol, 2009; 9: 97

Hald T, Vose D, Wegener HC, Koupeev T. A Bayesian approach to quantify the contribution of animal-food sources to human salmonellosis. Risk Anal, 2004; 24: 255-269.

Hoorfar J, Mortensen AV. Improved culture methods for isolation of Salmonella organisms from swine feces. Am. J. Ve.t Res, 2000; 61: 1426-1429.

Jyoti A, Ram S, Vajpaye0e P, Singh G, Dwivedi PD, Jain SK, Shanker R. Contamination of surface and potable water in South Asia by Salmonellae: Culture-Independent quantification with molecular beacon real-time PCR. Sci. Tot. Environ, 2010; 408: 1256-1263.

Liming SH, Bhagwat AA. Application of a molecular beaconreal-time PCR technology to detect Salmonella species contaminating fruits and vegetables. Int. J. Food Microbiol, 2004; 95: 177- 187.

Malkawi HI, Gharaibeh R. Multiplex PCR for the direct detection of Salmonella enterica from chicken, lamb and beef food products. J. Bas. Microbiol, 2003; 43: 328-336.

Malorny B, Hoorfar J, Bunge C, Helmuth R. Multicenter Validation of the Analytical Accuracy of Salmonella PCR: towards an International Standard. Appl. Environ. Microbiol, 2003; 69: 290-296.

Malorny B, Lo"fstro"m C, Wagner M, Kra"mer N, Hoorfar J. Enumeration of Salmonella bacteria in food and feed samples by real-time PCR for quantitative microbial risk assessment. Appl. Environ. Microbiol, 2008; 74: 1299-1304.

Moganedi KLM, Goyvaerts EMA, Venter SN, Sibara MM. Optimisation of the PCR-invA primers for the detection of Salmonella in drinking and surface waters following a pre-cultivation step. Water. SA, 2007; 33: 195-202.

Park, HJ, Kim HJ, Park SH, Shin EG, Kim JH, Kim HY. Direct and quantitative analysis of Salmonella enterica serovar typhimurium using Real-Time PCR from artificially contaminated chicken meat. J. Microbiol. Biotechnol, 2008; 18: 1453-1458.

Patel JR, Bhagwat AA, Sanglay GC, Solomon MB. Rapid detection of Salmonella from hydrodynamic pressure-treated poultry using molecular beacon real-time PCR. Food Microbiol, 2006; 23: 39-46.

Perelle S, Dilasser F, Malorny B, Grout J, Hoorfar J, Fach P. Comparison of PCR-ELISA and Light Cycler real-time PCR assays for detecting Salmonella spp. in milk and meat samples. Mol. Cell Prob, 2004; 18: 409-420.

Rahn K, De Grandis SA, Clarke RC, McEwen SA, Gala'n JE, Ginocchio C, Curtiss III R, Gyles CL. Amplification of an invA gene sequence of Salmonella typhimurium by polymerase chain reaction as a specific method of detection of Salmonella. Mol. Cell. Prob, 1992; 6: 27179.

Singh J, Batish VK, Grover S. Molecular beacon based realtime PCR assay for simultaneous detection of Listeria monocytogenes and Salmonella spp. in dairy products. Dair. Sci. Technol, 2011; 91: 373-382. 
Tomar RS, Jyoti A. Designing Computation and In-silico validation of real-time PCR primers and molecular beacon probe for quantitative detection of Salmonellae. Pharmanest, 2015; 6: 2620-2624.

Uyttendaele M, Vanwildemeersch K, Debevere J. Evaluation of real-time PCR vs automated ELISA and a conventional culture method using a semi-solid medium for detection of Salmonella. Lett. Appl. Microbiol, 2003; 37: 386-391.

Voetsch AC, Gilder TJV, Angulo FJ, Farley MM, Shallow S, Marcus R. Food Net estimate of the burden of illness caused by nontyphoidal Salmonella infections in the United States. Clin. Infect. Dis, 2004; 38: 27-34.
Yoshida C, Franklin K, Konczy P, McQuiston JR, Fields PI, Nash JH, Taboada EN, Rahn K. Methodologies towards the development of an oligonucleotide microarray for determination of Salmonella serotypes. J. Microbiol. Meth. 2007; 70: 261-271.

\section{How to cite this article:}

Tomar RS, Jyoti A. Culture-independent quantification of Salmonellae in food by molecular beacon based real-time PCR. J App Pharm Sci, 2016; 6 (11): 153-157. 